\begin{tabular}{|c|c|c|}
\hline 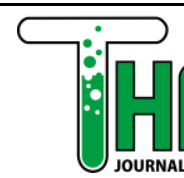 & TURAL SCIENCE TEACHING & $\begin{array}{l}\text { Thabiea : Journal of Natural Science Teaching } \\
\text { Vol. 3(2), pp. 95-109, } 2020 \\
\text { Available online at } \\
\text { http://journal.iainkudus.ac.id/index.php/Thabiea } \\
\text { p-issn: 2580-8474, e-issn: } 2655-898 X\end{array}$ \\
\hline
\end{tabular}

\title{
Family Foodstuff Inventory as Biology Learning Source of Biodiversity Concept in the Covid-19 Pandemic
}

\author{
Hanin Niswatul Fauziah*, Widya Retno Putri, Riya Mayangsari, Amiliana Zaratul \\ Shima, Hanip Heri Heriyawan, and Bagus Sapto Raharjo
}

\author{
Natural Sciences Education Department, Faculty of Tarbiyah and Teacher Training, \\ IAIN Ponorogo, East Java, Indonesia \\ *Correspondence: haninhusein@gmail.com
}

\begin{tabular}{ll}
\hline & Abstract \\
\hline Keywords: & Since Covid-19 pandemic government requires all educational institution to apply \\
COVID-19 & online learning. Therefore, they must be able to use local potential as a learning source \\
foodstuffs & as much as possible. One of the local potentials used as a learning source is \\
inventory & implementing an inventory of family foodstuffs. This research aimed to determine the \\
pandemic & type of foodstuff consumed by the biology college student's families in the Covid-19 \\
plants & pandemic and how to integrate it into the biology learning of biodiversity concept. \\
& Data were collected by observing the foodstuffs of 28 biology college students's \\
& families. Every college student recorded the food consumed by his family for two \\
& weeks. The data were foodstuffs name, part of foodstuffs consumed and its benefits. \\
& Consumed foodstuffs will be sampled, photographed, and identified up to the family \\
& level. Foodstuff for every college student's family were tabulated into Microsoft Excel \\
& and collected into class data and then analyzed descriptively. Results showed there \\
& were 2 types of foodstuffs consumed by the biology student's families namely \\
& vegetable and animal foodstuff. The most consumed vegetables during the Covid-19 \\
pandemic came from Fabaceae of 15 species and the most consumed animal came & from Bovidae of 2 species. Inventory of family foodstuffs during Covid-19 pandemic \\
& can be used as a biology learning source of biodiversity. After knowing the taxa of \\
& each foodstuff, college students ccould categorize the level of biodiversity. Integrating \\
the environment as a learning source make learning more applicable, varied, & interesting, and easier for college students to understand the materialbeing studied
\end{tabular}

To cite this article:

Fauziah, H. N., Widya R. P., Riya M., Amiliana Z. S., Hanip H. H., \& Bagus S. R. (2020). Family Foodstuff Inventory as Biology Learning Source of Biodiversity Concept in the Covid-19 Pandemic. Thabiea : Journal of Natural Science Teaching, 3(2), 95-109.

\section{Introduction}

Indonesia is an archipelago located between two continents, Asia and Australia. Indonesia has approximately 17,500 islands from Sabang to Merauke with an area is around 9 million $\mathrm{km}^{2}$ and a coastline is around $95,181 \mathrm{~km}$. The geographical conditions cause In donesia to be one of the world's mega biodiversity countries (Kusmana \& Hikmat, 2015). In Indonesia, there are an estimated 515 mammals (39\% endemic), 511 reptilian species (30\% endemic), 1531 bird species (20\% endemic), and 270 amphibian species (40\% endemic) (Triyono, 2013). As for plant diversity, it is estimated that there are 30,000-40,000 vascular plants. The plants diversity provides many benefits for the Indonesian population including providing environmental services, socio-cultural, medicines, building materials, and foodstuffs (Muraqmi et al., 2015). There are so 
many plants in Indonesia that have potential as foodstuff, but unfortunately, not all Indonesians know and want to use them.

Potential plants for foodstuffs are plants that have organs or parts that can be utilized for human consumption by processing or eating raw because contain nutrients that are good for the body and non-toxic (Prabaningrum et al., 2018). Indonesians consume a variety of foodstuffs. No less than 100 types of nuts, 450 types of fruits, and 250 types of vegetables and mushrooms. Based on IBSAP data (2015), the majority of foodstuffs consumed by Indonesians come from fruits and vegetables, which are 450 types of fruit and 250 types of vegetables (Walujo, 2011). Besides plants, foodstuff is also derived from animals. Animals are needed by humans as an animal protein source. Animal foodstuffs include food from husbandry products (meat, eggs, and milk) and fisheries commodities. Animal foodstuff groups are divided into seven subgroups, namely sea fish, shrimp, freshwater fish, salted fish, meat, eggs, and milk. Animal foodstuff is consumed to fulfill the needs of animal protein (Ariani et al., 2018).

Protein is needed for the growth and development of children under five years (Ariani et al., 2018). The quality of animal protein consumption is better than vegetable proteins due to the amino acids contained are more complete and the absorption capacity in the body is also higher. Based on the analysis results of the Food Security Agency (Badan Keamanan Pangan=BKP), it is known that the pattern of Indonesian people's food consumption is still dominated by carbohydrates or vegetables. In 2014, consumption of vegetable protein was around $68.9 \%$ and animal protein was around 31.1\%. Consumption of animal protein in Ind onesia is still low than in neighboring countries. Based on data from the Food and Agriculture Organization (FAO) in 2003 2005, consumption of animal protein per capita/day in Indonesia was only around 20-30 grams while in Malaysia, and Brunei Darussalam was around 50-60 grams. Protein is needed to support biological processes in the human body; one of the biological processes is the immune function. A good immune system is needed to prevent the body from various diseases (Hariyadi, 2011) one of them caused by a virus.

Now, more than 200 countries are experiencing a COVID-19 pandemic. COVID-19 was first identified as a disease that infects the respiratory system of the Wuhan Chinese population. As of March 31, 2020, there were 719,758 confirmed COVID-19 and 33,673 people died in the world. In Indonesia on March 31, there were 1,528 confirmed Covid-19 and 136 people died (Setiati \& Azwar, 2020). It has caused many countries to set lockdown policies and social distancing and Indonesia is no exception (Engkus et al., 2020). Indonesian government sets a lockdown policy and social distancing to suppress the spread of Covid-19 because it could break the chain of the spread of the virus.

Lockdown and social distancing cause changes in various Indonesia society life sectors, for example, the economy (Joharudin et al., 2020), agriculture, animal husbandry, trade, employment, income, and education. In agriculture and animal husbandry, farmers and ranchers have difficulty in distributing their businesses. Difficulties in this distribution will affect the fulfillment of food needs for other regions. In education, the government requires all educational institutions to apply online learning. Natural Sciences Education Department, IAIN Ponorogo is one of the institutions that has implemented online lectures. Because the lecture activities are held by online methods, they must be able to use local potential as a learning source as much as possible. One of the local potentials that can be used as a source of learning is implementing an inventory of family foodstuffs during the Covid-19 pandemic as a biology learning source for 
biodiversity concepts. By implementing an inventory of family foodstuff during the Covid-19 pandemic, college students can learn diversity without having to go to the botanical garden.

Based on the description, it is necessary to do an inventory of family foodstuffs. This inventory is implemented to determine the types of consumed foodstuff by families during the COVID-19 pandemic as well as a biology source learning of biodiversity concept for college students of the Natural Sciences Education Department, IAIN Ponorogo. Inventory is the right way to learn the biodiversity concept because there is an identification activity to classify foodstuffs based on the taxa in the inventory. After that, college students can categorize their biodiversity levels. This research aimed to determine the type of foodstuff consumed by the biology college student's families in the COVID-19 pandemic and how to integrate it into the biology learning of biodiversity concepts.

\section{Method}

This research was conducted from April to June 2020. Data were collected by observing the biology college students's families foodstuffs, Natural Science Education Department, IAIN Ponorogo. There are 28 college students consisting of 21 women and $7 \mathrm{men}$. They come from families with a middle economy. Their domiciles are in the Madiun Residency (Ponorogo, Pacitan, Ngawi, Madiun, and Magetan). Every college student observed foodstuffs consumed by their family for two weeks, starting from 1 to April 14, 2020. The data collected were food stuffs name, part of foodstuffs consumed, and its benefits. Sample were taken for every foodstuff consumed, and then photographed, and identified up to family level. Foodstuffs for every college student's family were tabulated into Microsoft Excel and collected into class data and then analyzed descriptively.

\section{Results and Discussion}

\section{Types of Foodstuff Consumed by College Student Families in the Covid-19 Pandemic Period}

The results showed that the foodstuffs consumed by college student's families in the Covid-19 pandemic period there were 98 plant species from 38 families and 15 animal species from 14 families (Table 1). The most consumed plant as foodstuffs came from the Fabaceae family with a total of 15 species. They are ale, tamarind, sengkang, beans, turi, gude beans, green beans, koro bean, long beans, peanuts, tolo beans, soybeans, black soybeans, petai and lamtoro. While the least consumed as foodstuffs came from the Gnetaceae, Caricaceae, Alliaceae, Amaranthaceae, Lamiaceae, Piperaceae. Myristicaeae, Lauraceae, Tricholomataceae, Flacourtiaceae, Pandanaceae, Rubiaceae, and Rosaceae which was consist of one species. Besides plants, several animals are used as a foodstuff. The most consumed animal as a foodstuff in the Covid-19 pandemic period came from the Bovidae family with a total of 2 species, cows, and goats.

The Fabaceae and Bovidae families were the most consumed by biology college student's families because most of them have come from Ponorogo and Madiun, which are famous for its satay and pecel culinary. Ponorogo is famous for its culinary chicken satay and pecel kepleh (Rahmawati et al., 2018), while Madiun is famous for its culinary Madiun pecel. Satay often found is usually made from chicken, goat and beef served with peanut sauce and 
soybean sauce. Soybean sauce is one of the traditional fermented foods of soybeans which are widely used as a food flavoring in Indonesia (Naiola \& Soeka, 2007), which soybeans are included in the Fabaceae family. While pecel (Figure 1.) is an Indonesian food made from a vegetable stew served with watered peanut sauce (Lasmanawati, 2009). The main ingredients of the sauce pecel are peanuts and chilies mixed with other ingredients such as purut lime leaves, onions, and tamarind. Pecel can be made by anyone, so pecel is also served at home as a family meal because it is easy to make. It just boils vegetables. Vegetables that used for pecel were various, such as string beans, koro bean and turi, they are come from Fabaceae family. Pecel is usually also equipped with peanut brittle and tempeh made from soybeans. Soybeans, green beans, peanuts and tolo bean that belong to the Fabaceae family are processed into peanut brittle. Although Ponorogo and Madiun are famous for their pecel culinary, both of them have differences. The differences are in the pecel sauce and their side dishes. According to Hanin (2019) Ponorogo sambal pecel does not use a spice, temu kunci (Boesenbergia rotunda) while Madiun sambal pecel uses a spice, temu kunci (Boesenbergia rotunda). Tempeh in Ponorogo pecel is tempeh kepleh, which is thinly thin tempeh and fried medium. While tempeh in Madiun pecel is tempeh sliced in medium-size and fried until cooked.

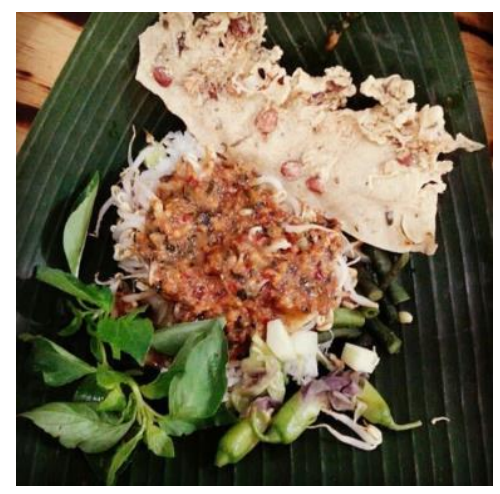

Figure 1. Pecel (Pebrianti, 2019)

Animal foodstuffs derived from the Bovidae family namely goats and cows. Goat meat aside from being processed into satay can also be processed into tongseng and curry. While beef, generally used as meatballs. According to (Fauziah, 2014), meatballs are very popular foods in Indonesia. Almost all types of society like this food, so, it is not surprising that meatball sellers are found in every region in Indonesia. According to the Indonesian National Standards, meat content in meatballs at least $50 \%$, but in reality, many meatball sellers make meatballs with less than $50 \%$ meat content. It implements to reduce production costs. Even "Aci Meatball" or well-known as "cilok" contains only a little meat (less than $10 \%)$. 
Table 1. Family of Food stuffs in the COVID-19 Pandemic

\begin{tabular}{|c|c|c|c|}
\hline No & Scientific Name & Local Name & Part(s) Used \\
\hline \multirow[t]{17}{*}{1} & Family of Fabaceae & & \\
\hline & Acacia nilotica ssp. tomentosa & Ale & Seed \\
\hline & Tamarindus indica & Tamarind & Fruit, leaf \\
\hline & Pachyrhizus erosus & Yam bean & Bulbs \\
\hline & Phaseolus vulgaris & Green Bean & Pod \\
\hline & Sesbania grandiflora & Turi & Flower \\
\hline & Cajanus cajan & Gude Beans & Seed \\
\hline & Vigna radiata & Green Beans & Seed \\
\hline & Canavalia ensiformis & Koro Beans & Pod \\
\hline & Phaseolus vulgaris & Kidney Beans & Seed \\
\hline & Vigna unguiculata & Long Beans & Pod, leaf \\
\hline & Arachis hypogeae & Peanut & Seed \\
\hline & Vigna unguiculata & Tolo Beans & Seed \\
\hline & Glycine $\max$ L. Merr & Soybeans & Seed \\
\hline & Glycine soja & Black Soybean & Seed \\
\hline & Parkia speciosa & Stink Beans & Seed \\
\hline & Leucaena leucocephala & Lamtoro & Seed \\
\hline \multirow[t]{9}{*}{2} & Family of Cucurbitaceae & & \\
\hline & Benincasa hispida & Bligo & Fruit \\
\hline & Luffa acutangula & Luffa Angled & Fruit \\
\hline & Momordica charantia & Bitter Gourd & Fruit \\
\hline & Trichosanthes cucumerina & Snake Gourd & Fruit \\
\hline & Sechium edule & Manisah/Japan & Fruit \\
\hline & Cucumis sativus & Cucumber & Fruit \\
\hline & Cucubita moschata Durch & Pumpkin & Fruit \\
\hline & Cutrillus lanatus & Watermelon & Fruit \\
\hline \multirow[t]{7}{*}{3} & Family of Solanaceae & & \\
\hline & Solanum melongena & Eggplant & Fruit \\
\hline & Solanum lycopersicum & Tomato & Fruit \\
\hline & Capsicum annum $L$. & Big Green Chili & Fruit \\
\hline & Capsicum annum $L$. & Big Red Chili & Fruit \\
\hline & Capsicum frutescens $L$. & Chili & Fruit \\
\hline & Solanum tuberosum L. & Potato & Bulbs \\
\hline \multirow[t]{7}{*}{4} & Family of Arecaceae & & \\
\hline & Arenga pinnata & Sugar Palm & Roomie \\
\hline & Cocos nucifera $L$. & Coconut & Fruit \\
\hline & Elaeis guineensis Jacq. & Palm oil & Fruit \\
\hline & Metroxylon sagu & Sago & Stem \\
\hline & Sallaca zalacca & Snake Fruit & Fruit \\
\hline & Colocasia esculenta & Taro & Bulbs \\
\hline \multirow[t]{6}{*}{5} & Family of Zingiberaceae & & \\
\hline & Boesenbergia pandurata & Temu Kunci & Rhizome \\
\hline & Curcuma longa & Turmeric & Rhizome \\
\hline & Alpinia galanga & Galangal & Rhizome \\
\hline & Kaempferia Galanga & Aromatic Ginger & Rhizome \\
\hline & Zingiber officinale & Ginger & Rhizome \\
\hline \multirow[t]{2}{*}{6} & Family of Brassicaceae & & \\
\hline & Brassica oleraceae var. italica & Broccoli & Flower \\
\hline
\end{tabular}




\begin{tabular}{|c|c|c|c|}
\hline No & Scientific Name & Local Name & Part(s) Used \\
\hline & Brassica oleraceae var. botrytis & Cauliflower & Flower \\
\hline & Brassica chinensis & Mustard Green & Leaf \\
\hline & Brassica rapa & Chinese Cabbage & Leaf \\
\hline & Brassica oleracea var. Capitata $L$. & Cabbage & Leaf \\
\hline \multirow[t]{5}{*}{7} & Family of Amarylidaceae & & \\
\hline & Allium cepa $L$ & Onion & Bulbs \\
\hline & Allium sativum & Garlic & Bulbs \\
\hline & Allium ampeloparsum & Leek & leaf, stem \\
\hline & Allium schoenoprasum & Spring onion & leaf, stem \\
\hline \multirow[t]{5}{*}{8} & Family of Poaceae & & \\
\hline & Cymbopogon citratus & Lemongrass & leaf, stem \\
\hline & Triticum & Wheat & Seed \\
\hline & Zea mays & Corn & Seed \\
\hline & Saccharum officinarum $L$ & Cane & Stem \\
\hline \multirow[t]{5}{*}{9} & Family of Apiaceae & & \\
\hline & Apium graveolens & Celery & leaf, stem \\
\hline & Trachyspermum roxburghianum & Caraway & Seed \\
\hline & Coriandrum sativum & Coriander & Seed \\
\hline & Daucus carota & Carrot & Bulbs \\
\hline \multirow[t]{4}{*}{10} & Family of Rutaceae & & \\
\hline & Citrus $x$ aurantiifolia & Lime & Fruit \\
\hline & Citrus sinensis & Kaffir Lime & Leaf \\
\hline & Citrus hystrix & Sweet Orange & Fruit \\
\hline \multirow[t]{4}{*}{11} & Family of Asteraceae & & \\
\hline & Cosmos caudatus & Kenikir & Leaf \\
\hline & Pluchea indica & Beluntas & Leaf \\
\hline & Lactuca sativa & Green Lettuce & Leaf \\
\hline \multirow[t]{4}{*}{12} & Family of Myrtaceae & & \\
\hline & Syzygium polyanthum & Bay leaf & Leaf \\
\hline & Psidium guajava & Guava & Fruit \\
\hline & Syzygium aromaticum & Clove & Flower \\
\hline \multirow[t]{3}{*}{13} & Family of Euphorbiaceae & & \\
\hline & Aleurites moluccana & Candlenut & Seed \\
\hline & Manihot esculenta & Cassava & Bulbs, leaf \\
\hline \multirow[t]{3}{*}{14} & Family of Sapindaceae & & \\
\hline & Nephelium lappaceum & Rambutan & Fruit \\
\hline & Filicium decipiens & Krai & Fruit \\
\hline \multirow[t]{3}{*}{15} & Family of Moraceae & & \\
\hline & Artocarpus camansi & Breadnut & Fruit \\
\hline & Artocarpus heterophyllus & Jackfruit & Fruit \\
\hline \multirow[t]{3}{*}{16} & Family of Gramineae & & \\
\hline & Oryza sativa & Rice & Seed \\
\hline & Oryza sativa var glutinosa & Sticky rice & Seed \\
\hline \multirow[t]{3}{*}{17} & Family of Convolvulaceae & & \\
\hline & Ipomea aquatic Forsk & Spinach water & Leaf, Stem \\
\hline & Ipomoea batatas & Sweet Potato & Bulbs \\
\hline \multirow[t]{2}{*}{18} & Family of Gnetaceae & & \\
\hline & Gnetum gnemon & Melinjo & Leaf, Seed, Flower \\
\hline
\end{tabular}




\begin{tabular}{|c|c|c|c|}
\hline No & Scientific Name & Local Name & Part(s) Used \\
\hline \multirow[t]{2}{*}{19} & Family of Caricaceae & & \\
\hline & Carica papaya & Papaya & Fruit, Flower, Leaf \\
\hline \multirow[t]{2}{*}{20} & Family of Alliaceae & & \\
\hline & Allium tuberosum & Chives & Leaf \\
\hline \multirow[t]{2}{*}{21} & Family of Amaranthaceae & & \\
\hline & Amaranthus sp & Spinach & Leaf \\
\hline \multirow[t]{2}{*}{22} & Family of Lamiaceae & & \\
\hline & Ocimum americanum & Basil & Leaf \\
\hline \multirow[t]{2}{*}{23} & Family of Piperaceae & & \\
\hline & Piper nigrum & Pepper & Seed \\
\hline \multirow[t]{2}{*}{24} & Family of Myristicaeae & & \\
\hline & Myristica fragrans & Nutmeg & Seed \\
\hline \multirow[t]{2}{*}{25} & Family of Lauraceae & & \\
\hline & Cinnamomum verum J. Presl & Cinnamon & Bark \\
\hline \multirow[t]{2}{*}{26} & Family of Tricholomataceae & & \\
\hline & Pleurotus ostreatus & Oyster Mushroom & Mushroom cap \\
\hline \multirow[t]{2}{*}{27} & Family of Flacourtiaceae & & \\
\hline & Pangium edule Reinw & Kluwak & Fruit \\
\hline \multirow[t]{2}{*}{28} & Family of Pandanaceae & & \\
\hline & Pandanus amaryllifolius & Fragrant Pandan & Leaf \\
\hline \multirow[t]{2}{*}{29} & Family of Rubiaceae & & \\
\hline & Coffea canephora Pierre & Coffee & Seed \\
\hline \multirow[t]{2}{*}{30} & Family of Rosaceae & & \\
\hline & Malus domestica & Apple & Fruit \\
\hline \multirow[t]{2}{*}{31} & Family of Cactaceae Juss & & \\
\hline & Hylocereus undatus & Dragon Fruit & Fruit \\
\hline \multirow[t]{2}{*}{32} & Family of Musaceae & & \\
\hline & Musa sp. & Banana & Fruit \\
\hline \multirow[t]{2}{*}{33} & Family of Annonaceae & & \\
\hline & Annona squamosa & Custard apple & Fruit \\
\hline \multirow[t]{2}{*}{34} & Family of Clusiaceae & & \\
\hline & Garcinia mangostana & Mangosteen & Fruit \\
\hline \multirow[t]{2}{*}{35} & Family of Bromeliaceae & & \\
\hline & Ananas comosus & Pineapple & Fruit \\
\hline \multirow[t]{2}{*}{36} & Family of Malvaceae & & \\
\hline & Theobroma cacao & Chocolate & Fruit \\
\hline \multirow[t]{2}{*}{37} & Family of Meliaceae & & \\
\hline & Lansium domesticum & Duku & Fruit \\
\hline \multirow[t]{2}{*}{38} & Family of Dioscoreaceae & & \\
\hline & Dioscorea hispida & Gadung & Bulbs \\
\hline \multirow[t]{2}{*}{39} & Family of Phasianidae & & \\
\hline & Gallus gallus domesticus & Chicken & Meat \\
\hline \multirow[t]{2}{*}{40} & Family of Anatidae & & \\
\hline & Anas platyrhynchos domesticus & Duck & Meat \\
\hline \multirow[t]{3}{*}{41} & Family of Bovidae & & \\
\hline & Capra aegagrus hircus & Goat & Meat, skin \\
\hline & Bos taurus & Cow & Meat, skin, milk \\
\hline
\end{tabular}




\begin{tabular}{|c|c|c|c|}
\hline No & Scientific Name & Local Name & Part(s) Used \\
\hline & Caridea & Shrimp & Meat \\
\hline \multirow[t]{2}{*}{43} & Family of Caprimulgidae & & \\
\hline & Caprimulgus affinis & Cabak & Meat \\
\hline \multirow[t]{2}{*}{44} & Family of Chanidae & & \\
\hline & Chanos chanos & Milkfish & Meat \\
\hline \multirow[t]{2}{*}{45} & Family of Synbranchidae & & \\
\hline & Monopterus albus & Eel & Meat \\
\hline \multirow[t]{2}{*}{46} & Family of Clariidae & & \\
\hline & Clarias & Catfish & Meat \\
\hline \multirow[t]{2}{*}{47} & Family of Menidae & & \\
\hline & Mene maculata & Semar fish & Meat \\
\hline \multirow[t]{2}{*}{48} & Family of Engraulidae & & \\
\hline & Engraulidae & Anchovy & Meat \\
\hline \multirow[t]{2}{*}{49} & Family of Giganturidae & & \\
\hline & Gigantura chuni & Ikan teropong & Meat \\
\hline \multirow[t]{2}{*}{50} & Family of Scombridae & & \\
\hline & Euthynnus affinis & Mackarel tuna & Meat \\
\hline \multirow[t]{2}{*}{51} & Family of Cyprinidae & & \\
\hline & Barbodes binotatus & Wader fish & Meat \\
\hline \multirow[t]{2}{*}{52} & Family of Solieraceae & & \\
\hline & Gracilaria verrucosa & Seaweed & Thallus \\
\hline
\end{tabular}

The results showed that $55 \%$ of the plants used as a family foodstuff in the Covid-19 pandemic period were annual crops, while the remaining $45 \%$ were perennial crops (Figure 2). One of the annual plants is potato. Potatoes are one of the most widely cultivated plants by farmers in Indonesia (Hidayat \& Efendi, 2018). Potatoes are one of the world's five main crops except rice, corn, wheat, and sorghum (Rosanna et al., 2014). Many annual crops are cultivated because annual crops can be used as a foodstuff. Annual crops also characterize sustainable agriculture as providing conservation, reclamation, and economic value. Annual crops are a plant that has a spreading root system. Plants with a spreading root system are perfect for planting on sloping land. Plant roots will enlarge the soil pore so that soil porosity will be high and more water will enter the soil surface. It can reduce soil erosion in the rainy season (Febriyandra, 2017; Kurnia, 2004).

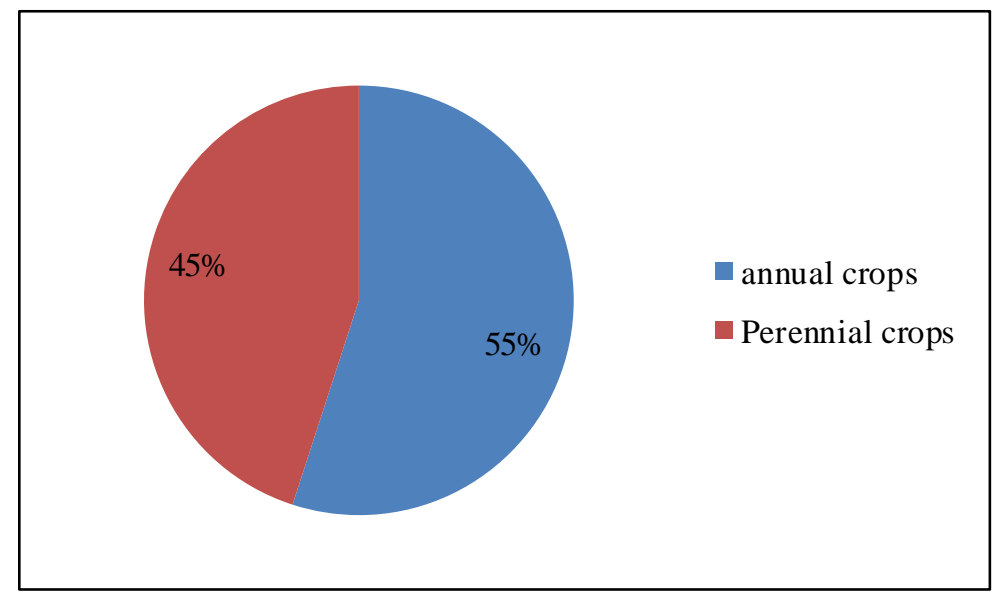

Figure 2. Percentage of Plant Life Cycle as Family Foodstuffs in the Covid-19 Pandemic 
Parts of plants used as family foodstuffs are leaves, flowers, seeds, pods, fruit, stems, bulbs, rhizomes, mushroom hoods, bark, and sap. The most used plant parts as foodstuff are fruits $(30 \%)$, followed by leaves $(20 \%)$, seeds (19\%), bulbs $(9 \%)$, stems $(6 \%)$, flowers $(5 \%)$, rhizomes $(4 \%)$, pods $(3 \%)$, bark (1\%), mushroom cap $(1 \%)$, sap $(1 \%)$ and thallus $(1 \%)$ (Figure 3). Plant parts in the form of fruit that are most widely used as family foodstuff include tamarind, beligo, luffa angled, bitter gourd, snake gourd, manisha/japan, cucumber, pumpkin, watermelon, eggplant, tomato, big green chili, big red chili, chili, coconut, palm, snake fruit, lime, sweet orange, guava, rambutan, krai, breadnut, jackfruit, papaya, kluwak, apple, dragon fruit, banana, srikaya, mangosteen, pineapple, chocolate, and $d u k u$. The fruit is the most of the plant that used as a food stuff, because the fruit has a distinctive taste (Sembori \& Tanjung, 2009) and it contains many vitamins, for example, vitamins A, C, and E. During the Covid-19 pandemic, the body needs enough vitamins to enhance the body's immune system. The human body has an immune system to fight viruses and bacteria that cause disease. If the immune system is good, the body will not be easily infected by viruses. However, there are some things that can weaken a person's immune system such as aging, malnutrition, disease, and even certain drugs. Therefore, the function of the immune system needs to be maintained so that the immune system is strong (Zendrato, 2020). According to (Arifin et al., 2020), one of the ways to enhance the immune system during the COVID-19 pandemic is to consume healthy foods and drinks and contain balanced nutrition. Besides that, the immune system can also be enhanced by regular exercise, adequate rest, sunbathing, and managing stress well (Zend rato, 2020).

The leaves are part of the second-largest plant that is used as foodstuffs, as many as 22 species. They are mustard greens, Chinese cabbage, cabbage, kaffir lime, kenikir, beluntas, lettuce, bay leaves, melinjo, papaya, chives, spinach, basil, pandanus, etc. The leaves are the most dominant plant parts because these plant parts are more easily collected than other plant parts. In the scientific view, leaves are the site of photosynthesis and the place of production of secondary metabolites. Besides that, consuming leaves is an effort to conserve plants, if consuming part of the root will cause the plant die, so that, the plant species can be threatened with extinction (Yurlisa et al., 2017). Parts of the plant are used as vegetables, food seasonings, food coloring, and medicine.

Long beans leave, mustard greens, Chinese cabbage, cabbage, kenikir, beluntas, lettuce, cassava, spinach water, melinjo, papaya, and spinach are used as vegetables. Bay leaves, chives, basil, and fragrant pandan are used as a food flavoring. Green mustard and pandan leaves are used as natural colour. While beluntas leaves, bay leaves, kenikir leaves, papaya leaves, and fragrant pandan leaves are used as herbal medicine. Papaya leaves have long been used by community groups for treatment, such as malaria pain medication, appetite enhancer, worm medicine, kidney stone medication, shed menstruation, and relieve pain. Papaya leaves contain various compounds such as flavonoids, papain enzymes, saccharose, dextrose, levulose, protein, carbohydrates, calcium, phosphorus, iron vitamin A, vitamin B1, vitamin C, water, and calories (Afrianti et al., 2014). According to Tasia \& Widyaningsih, (2014) pandan leaves, besides being used as natural colour and food flavorings, can also be used as herbal drinks, because they contain alkaloids, saponins, flavonoids, tannins, polyphenols, and dyes. Pandanus can increase appetite, blacken hair, eliminate dandruff, 
reduce hair loss, cure thyroid, and treat weaken nerves and provide calm for people who experience pain accompanied by anxiety.

Seeds are parts of plants that are used for various things, such as staple foods, vegetables, food seasonings, side dishes, and drinks. Seeds used as staple foods such as rice, wheat, and corn; as a side dish, for example, peanuts and soybeans; as vegetables such as green beans, gude beans, kidney beans, and tolo beans; as a food flavoring such as ale, black soybean, stink beans, lamtoro, caraway, coriander, candlenut, pepper, and nutmeg; and as a drink for example coffee. Bulbs are also parts of plants that can be used for various things, including vegetables, herbs (food seasonings), staple foods, and fruits. Bulbs that are used as vegetables include potatoes, taro, and carrots; as a seasoning (food flavoring) such as shallots and garlic; as staple food such as potatoes, gadung, and sweet potatoes; as fruits for example yam bean.

Stems that are used as staple food, such as sago. Stems as food flavoring are lemongrass and sugar cane. Besides being used as a flavoring, lemongrass also is used as medicine. Lemongrass treats skin infections, typhus, food poisoning, and relieve body odor (Arisanti \& Mutsyahidan, 2018). Flowers are used as vegetables such as turi, broccoli, and cauliflower. While that is used as a food flavoring is clove. Parts of the plant in the form of rhizomes are used as a seasoning for cooking such as temu kunci, turmeric, galangal, aromatic ginger, and ginger which are categorized as spices containing essential oils. Essential oils that evaporate in the cuisine produce a distinctive aroma and taste in the dish (Prabaningrum et al., 2018). Besides being used as food flavoring ingredients, spices also are used as herbal drinks (Hanin, 2019). Herbal drinks from spices have become a tradition of the Indonesian population and during the Covid-19 pandemic consumption of spices increased (Saragih \& Saragih, 2020). Spices like ginger, turmeric, and ginger can enhance the immune system. A good immune system will help the body to fight germs and viruses that attack cells of the human body. A good immune system will prevent the virus to infect the human body (Zendrato, 2020).

Pods are used as vegetables such as beans and kacang koro. Beans can be processed into stir-fry and soup while koro bean can be processed into lodeh. Part of the plant is utilized in the form of bark is cinnamon. Cinnamon is used as a flavor and aroma enhancer in foods and drinks, beside that cinnamon can also be used as medicine. According to Tasia \& Widyaningsih (2014) trans-sinamaldehid in cinnamon bark can be antioxidant that can prevent free radicals. Parts of plants in the form of the mushroom cap are oyster mushrooms commonly used as vegetables. Meanwhile, palm sugar plants are used as raw material for cooking food.

Some plants have 2 or more plant parts that can be consumed such as melinjo, long beans, tamarind, papaya, cassava, lemongrass, leek, spring onion, celery, and spinach water. Melinjo has 3 parts that can be consumed, flowers, leaves, and seeds. Long beans and tamarind have 2 parts that can be consumed, leaves, and pods. Besides tamarind leaves being used as a spice in cooking, it is also used as a drug for diabetes mellitus. Tamarind leaves can be used as a diabetes mellitus drug because it contains flavonoids, tannins, glycosides, and saponins (Lahamado et al., 2017). Cassava also has 2 parts that can be consumed, bulbs, and leaves. Besides, some plants can be consumed by leaves and stems such as leeks, spring 
onion, and celery which are used as food flavorings, and water spinach that are used as vegetables.

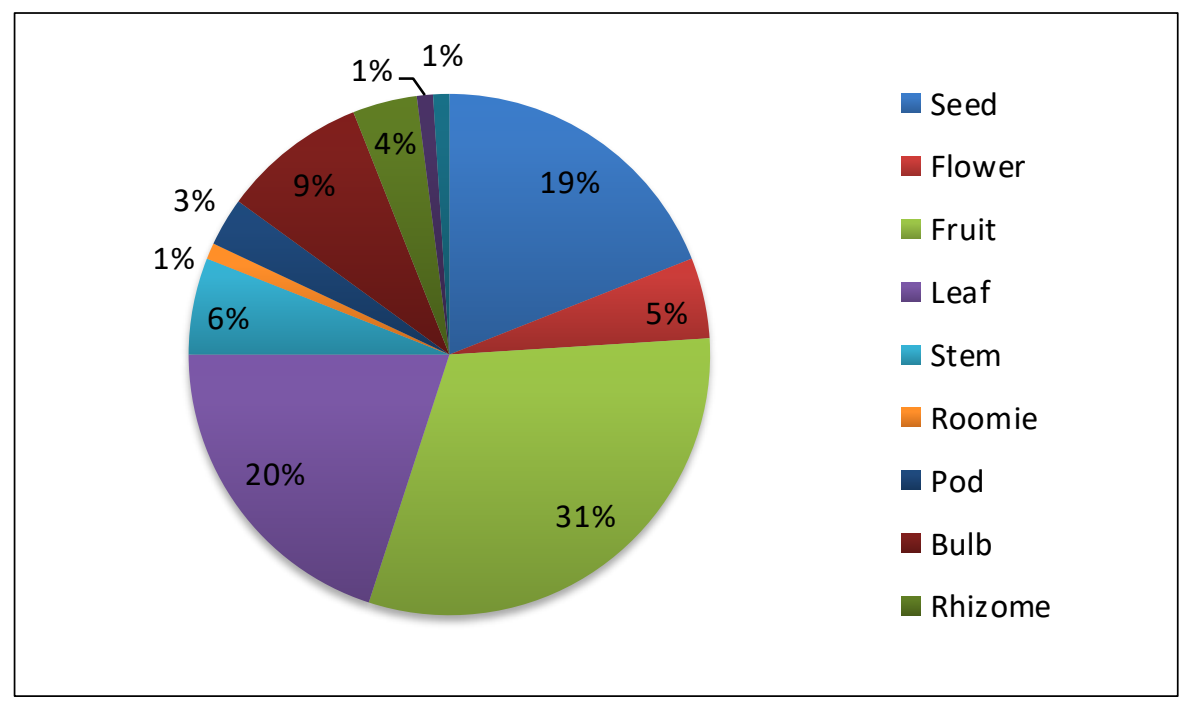

Figure 3. Percentage of Plant Part Used As Foodstuffs

Animals consumed during the Covid-19 pandemic included 14 families. There are Phasianidae, Anatidae, Bovidae, Malacostraca, Caprimulgidae, Canidae, Menidae, Engraulidae, Gigantiridae, Scrombridae, Cyprinidae, and Solieraceae (Figure 4). The most consumed animals come from the Bovidae family, goats (Capra aegagrus hircus), and cows (Bos taurus). The goat is taken meat and skin, while the cow is taken meat, skin, and milk. Cows are the most important animal as a source of meat, milk, labor, and other needs. Cows produce about $50 \%$ of the world's meat needs, $95 \%$ of milk needs, and $85 \%$ of cow's skin needs (Prasetyo et al., 2013). Cows came from Central Asia and then spread to Europe, Africa, and throughout Asia. In Indonesia, several local cows have high adaptability to low-quality feed, extensive maintenance systems, and have a good immune system in the tropical season. The goat is ruminant that potentially produce the meat. Goats can use natural ingredients and industrial products that are not consumed by human $\mathrm{s}$ as feed ingredients. The main food for goats is grass (Rudiah, 2011).

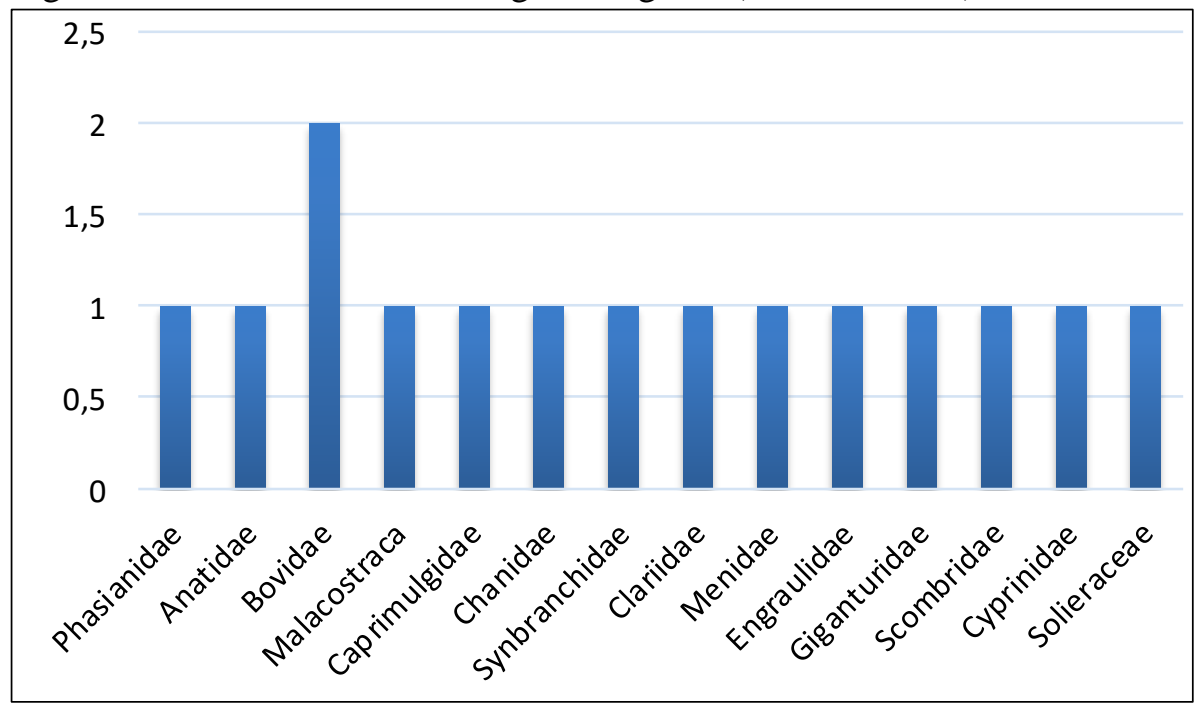

Figure 4. Graphic of Families that Used as Foodstuffs

Thabiea : Journal of Natural Science Teaching $-105-$ 


\section{Integration of Family Foodstuff Inventory as Biology Learning Source of Biodiversity Concepts}

The impact of the Covid-19 pandemic has penetrated education. International organizations in New York, United States of America said that education became one of the most impacted sectors of Covid-19 (Purwanto et al., 2020). Many countries have adopted an online learning policy to minimize the spread of Covid-19, including Indonesia. In Indonesia, all teaching and learning activities are carried out from home online and prohibit teaching and learning activities outside the home that use nature such as forests, beaches, lakes, and botanical gardens. Teaching and learning activities will certainly have an impact on subjects that require nature as a source of learning, one of the subjects is a biology course on the biodiversity concept. Biodiversity is the science that studies the diversity of living things. So, it requires nature as a source of learning. Therefore, an alternative solution is needed so that college students can still learn the biodiversity concept even though they stay at home.

One appropriate way to learn the biodiversity concept in the Covid-19 pandemic using the local potential around college students, one of them is home. According to Kahar \& Damayanti (2018), the use of local potential as a learning source is one of the efforts to create quality and creative teaching in the learning process. It can also attract the college students' interest and motivation so that learning becomes more meaningful and increasing their awareness of local potential. Besides that, learning biodiversity that raised local potential can also encourage the conservation of biodiversity in the future (Pratama et al., 2019). The utilization of houses as a learning source can be applied through an inventory of consumed food stuffs by college students' families in the Covid-19 pandemic.

During the foodstuff inventory activity, every college student was asked to observe consumed foodstuffs by their family during the Covid-19 pandemic. During the observation, college students not only record the plants and animals consumed by their families but also they have to pay attention to the availability of foodstuff, increased or decreased in the COVID-19 pandemic. By directed observation, college students learn to always be grateful for what has been obtained, understand and appreciate aspects of life in their environment, and learn to care for biodiversity. According to (Hanapi et al., 2017) directed learning by seeing real objects can improve environmental awareness.

Aspects that can used as learning source in this research were learning scenario used. In this scenario lecturer gave the college student assigns to record all of foodstuff consumed by their family for two weeks. College student took a sample for every foodstuff then took a photo, recorded the local name and part used. Then the sample was identified to the family level. When college student inventories their family foodstuffs, they also identify the foodstuff into taxa. After knowing the taxa from each foodstuff, students can categorize the level of biodiversity. The data that has been obtained then were collected into class data then analyzed and discussed. In the discussion section, students are asked to explain the level of biodiversity found and explain the relationship of family food diversity during the Covid-19 pandemic with socio-culture in the area where they live. Students can discover the concept of biodiversity by themselves through contextual learning because they learn the real object. 
Besides that, contextual learning by integrating local potential can make learning more varied and enjoyable.

\section{Conclusion}

The foodstuffs consumed by college student's families in the Covid-19 pandemic period there were 98 plant species from 38 families and 15 animal species from 14 families. The most consumed plant as foodstuffs came from the Fabaceae family with a total of 15 species. While the least consumed as foodstuffs came from the Gnetaceae, Caricaceae, Alliaceae, Amaranthaceae, Lamiaceae, Piperaceae. Myristicaeae, Lauraceae, Tricholomataceae, Flacourtiaceae, Pandanaceae, Rubiaceae, and Rosaceae which was consist of one species. The most consumed animal as foodstuff in the Covid-19 pandemic period came from the Bovidae family with a total of 2 species, cows and goats. Inventory of foodstuff family during the Covid-19 pandemic can be used as a biology learning source of biodiversity concept due to there is an identification of the consumed foodstuff into its taxa. After knowing the taxa college students can categorize the biodiversity level and explain the relationship between family foodstuffs diversity in the Covid-19 pandemic with their social culture.

\section{References}

Afrianti, R., Yenti, R., \& Meustika, D. (2014). Uji aktifitas analgetik ekstrak etanol daun pepaya (Carica papaya L.) pada mencit putih jantan yang di induksi asam asetat $1 \%$. Jurnal Sains Farmasi \& Klinis, 1(1), 54-60.

Ariani, M., Suryana, A., Suhartini, S. H., \& Saliem, H. P. (2018). Keragaan Konsumsi Pangan Hewani Berdasarkan Wilayah dan Pendapatan di Tingkat Rumah Tangga.

Arifin, T., Nuraeni, N., Mashudi, D., \& Saefudin, E. (2020). Proteksi diri saat pandemi COVID-19 berdasarkan hadits shahih.

Arisanti, D., \& Mutsyahidan, A. M. A. (2018). Karakterisitik sifat fisikokimia teh herbal" sekam"(serai kombinasi kayu manis) sebagai minuman fungsional. Jurnal Technopreneur (JTech), 6(2), 62-66.

Engkus, E., Suparman, N., Tri Sakti, F., \& Saeful Anwar, H. (2020). Covid-19: Kebijakan mitigasi penyebaran dan dampak sosial ekonomi di Indonesia. LP2M.

Fauziah, R. R. (2014). Kajian keamanan pangan bakso dan cilok yang berdar di lingkungan universitas jember ditinjau dari kandungan boraks, formalin dan TPC. Jurnal Agroteknologi, 8(01), 67-73.

Febriyandra, E. (2017). Pengaruh Beberapa Jenis Tanaman Semusim terhadap Aliran Permukaan Tanah di Desa Batu Gajah Kecamatan Pasir Penyu Kabupaten Indragiri Hulu [PhD Thesis]. Riau University.

Hanapi, E., Hariyono, H., \& Utaya, S. (2017). Pemanfaatan objek wisata sebagai sumber pembelajaran kontekstual. Prosiding Seminar Nasional Mahasiswa Kerjasama Direktorat Jenderal Guru Dan Tenaga Kependidikan Kemendikbud 2016.

Hanin, F. (2019). Inventarisasi Tanaman di Pasar Stasiun Ponorogo sebagai Sumber Belajar Biologi Mahasiswa Jurusan Tadris Ilmu Pengetahuan Alam, Institut Agama Islam Negeri Ponorogo. SEMESTA: Journal of Science Education and Teaching, 2(2), 4453.

Hariyadi, P. (2011). Importance and role of protein in the indonesia daily diet. Whey Protein Health and Fitness Seminar. Http://Www. Seafast. Ipb. Ac. Id/Publication/Presentation/USDEC-Protein-Whey-Jakarta-2011-Handouts. Pdf. 
Hidayat, Y. S., \& Efendi, D. (2018). Karakterisasi Morfologi Beberapa Genotipe Kentang (Solanum tuberosum) yang Dibudidayakan di Indonesia. Comm. Horticulturae Journal, 2(1), 28-34.

Joharudin, A., Septiadi, M. A., Maharani, S., Aisi, T. D., \& Nurwahyuningsih, N. (2020). Panic syndrom covid-19: penekanan terhadap kebijakan yang diberikan. Jurnal Perspektif, 4(1), 44-53.

Kahar, A. P., \& Damayanti, K. (2018). Pemanfaatan Potensi Lokal Sebagai Pondasi Konstruktivisme Guru Biologi Kabupaten Kubu Raya Mewujudkan Learning Biology Problem Orientation. Al-Khidmah, 1(1), 13-16.

Kurnia, U. (2004). Prospek pengairan pertanian tanaman semusim lahan kering. Jurnal Litbang Pertanian, 23(4), 130-138.

Kusmana, C., \& Hikmat, A. (2015). Keanekaragaman hayati flora di Indonesia. Journal of Natural Resources and Environmental Management, 5(2), 187-187.

Lahamado, O. T., Sabang, S. M., \& Mustapa, K. (2017). Ekstrak Daun Asam Jawa (Tamarindus Indica L.) Sebagai Antidiabetes. Jurnal Akademika Kimia, 6(1), 1-6.

Lasmanawati, E. (2009). Sate Nusantara. Universitas Pendidikan Indonesia. http://file.upi.edu/Direktori/FPTK/JUR._PEND._KESEJAHTERAAN_KELUARGA/ 195610201984032-ELLY_LASMANAWATI_W/sate.pdf

Muraqmi, A., Anam, S., \& Ramadhanil, R. (2015). Etnobotani masyarakat Bugis di Desa Lempe Kecamatan Dampal Selatan Kabupaten Tolitoli. Biocelebes, 9(2).

Naiola, E., \& Soeka, Y. S. (2007). Fermentasi Kecap dari Beberapa Jenis Kacang-Kacangan dengan Menggunakan Ragi Mutan Aspergillus sp. K-1 dan Aspergillus sp. K-1a. Berita Biologi, 8(5), 365-373.

Pebrianti, C. (2019). Promosikan Pecel Mangunsuman Ratusan Pincuk Nasi Pecel Dibagikan Gratis. $\quad$ https://food.detik.com/berita-boga/d-4421959/promosikan-pecelmangunsuman-ratusan-pincuk-nasi-pecel-dibagikan-gratis

Prabaningrum, H., Nugroho, A. S., \& Kaswinarni, F. (2018). Keanekaragaman tumbuhan yang berpotensi sebagai bahan pangan di cagar alam gebugan Semarang. Jurnal Biologi Dan Pembelajarannya, 5(2), 26-31.

Prasetyo, B., Sarwiyono, S., \& Surjowardojo, P. (2013). Hubungan Antara Diameter Lubang Puting Terhadap Tingkat Kejadian Mastitis. TERNAK TROPIKA Journal of Tropical Animal Production, 14(1), 15-20.

Pratama, B. P. K., Ali, R. N., \& Sulistiyowati, E. (2019). Pendidikan Biodiversitas Berbasis Potensi Lokal Pada Tingkat SMA/MA.

Purwanto, A., Pramono, R., Asbari, M., Hyun, C. C., Wijayanti, L. M., \& Putri, R. S. (2020). Studi Eksploratif Dampak Pandemi COVID-19 Terhadap Proses Pembelajaran Online di Sekolah Dasar. EduPsyCouns: Journal of Education, Psychology and Counseling, $2(1), 1-12$.

Rahmawati, K., Harsono, J., \& Djuwitaningsih, E. W. (2018). Analisis strategi (community building) pemerintah desa kupuk, kecamatan bungkal, kabupaten Ponorogo dalam pengembangan desa wisata kupuk. Indonesian Journal of Government and Communication Studies, 1(1), 28-41.

Rosanna, M. M., Baharuddin, E., \& Lisan, E. (2014). The Effectiveness Of Paclobutrazol And Organic Fertilizer For The Growth And Yield Of Potatoes (Solanumtuberosuml.) In Medium Plain. International Journal of Scientific and Technology Research, 3(7), $101-108$.

Rudiah, R. (2011). Respon Kambing Kacang Jantan Terhadap Waktu Pemberian Pakan. Media Litbang Sulteng, 4(1).

Saragih, B., \& Saragih, F. M. (2020). Hubungan berbagai faktor dengan kebiasaan makan pada masa pandemi covid 19. 
Sembori, F., \& Tanjung, R. H. (2009). Inventarisasi Jenis Tumbuhan Pangan Lokal pada Masyarakat Ambaidiru Distrik Kosiwo, Kabupaten Yapen Waropen. Jurnal Biologi Рариа, 1(1), 36-41.

Setiati, S., \& Azwar, M. K. (2020). COVID-19 and Indonesia. Acta Medica Indonesiana, 52(1), 84-89.

Tasia, W. R. N., \& Widyaningsih, T. D. (2014). Jurnal review: Potensi cincau hitam (mesona palustris bl.), daun pandan (pandanus amaryllifolius) dan kayu manis (cinnamomum burmannii) sebagai bahan baku minuman herbal fungsional [IN PRESS OKTOBER 2014]. Jurnal Pangan Dan Agroindustri, 2(4), 128-136.

Triyono, K. (2013). Keanekaragaman hayati dalam menunjang ketahanan pangan. Jurnal Inovasi Pertanian, 11(1), 12-22.

Walujo, E. B. (2011). Keanekaragaman hayati untuk pangan. KIPNAS X. LIPI, 1-9.

Yurlisa, K., Maghfoer, M. D., Aini, N., DY, W. S., \& Permanasari, P. N. (2017). Survey dan pendokumentasian sayuran lokal di pasar tradisional Kabupaten dan Kota Kediri, Jawa Timur. Jurnal Biodjati, 2(1), 52-63.

Zendrato, W. (2020). Gerakan mencegah daripada mengobati terhadap pandemi covid-19. JURNAL EDUCATION AND DEVELOPMENT, 8(2), 242-242. 